таких способностях государства, как: поддержание сложных и специализированных организаций, установление обезличенных отношений, обеспечение работы бессрочно существующего государства, а также контроль над дисперсией и испольованием насилия в обществе[6]. Этот подход открывает новые концептуальные рамки общественно-научного исследования, подрузамивающее более глубокое понимание природы насилия.

\title{
Литература:
}

1. Антипенко В.Ф. Теории мирового развития и антитеррористическое право. Логика сопрягаемости. К., 2007. 440 с.

2. Антипенко В.Ф. Теория уголовной ответственности государств : монография. Одесса: «Фенікс», 2016. 328 с.

3. Энгельс Ф. Происхождение семьи, частной собственности и государства: В связи с исследованиями Льюиса Г. Моргана. Москва: Издательство политической литературы, 1982. 240 с.

4. Здравомыслов А.Г. Социология конфликта: Россия на путях преодоления кризиса: пособ. М.: АсистПресс, 1994. 318 с.

5. Жуневель Б. Власть: Естественная история ее возрастания. М.: ИРИСЭН. Мысль. 2011. 546 с.

6. Норт Д., Уоллис Д., Вайнгаст Б. Насилие и социальные порядки. М.: Изд-во Института Гайдара, 2011. 482 с.

DOI https://doi.org/10.30525/978-9934-26-148-0-9

\section{ТРАНСПЛАНТАЦІЯ: ОСНОВНІ ПІДХОДИ ДО РОЗУМІННЯ}

\section{Попович Т. П.}

кандидат юридичних наук, дочент, доцент кафедри теорії та історії держави і права ДВНЗ «Ужгородський національний університет»

\section{Ільченко С. О.}

аспірант кафедри теорії та історії держави і права ДВНЗ «Ужгородський національний університет»

\author{
м. Ужгород, Україна
}

Трансплантація являє собою складний процес, що містить два основні етапи: перший - забір органів і тканин від донора, другий імплантацію останніх в організм реципієнта. При цьому, варто наголосити, що трансплантація може бути здійснена лише в тому 
випадку, коли інші медичні засоби не можуть гарантувати збереження життя реципієнта чи відновлення його здоров'я [1, с. 50].

Звернемось до окремих визначень феномену трансплантації, що містяться у науковій літературі. Так, В.I. Пішта визначає трансплантацію як процес пересадки анатомічних матеріалів реципієнту (особі, яка потребує пересадки) від донора (особи, яка погодилась надати свої органи чи тканини для подальшої трансплантації) [2, с. 87].

У своєму дисертаційному дослідженні Д.С. Донцов визначив поняття суспільних відносин у сфері клінічної трансплантації, що потребують спеціального цивільно-правового регулювання: це обумовлені необхідністю збереження життя чи відновлення здоров'я відносини, які виникають при вилученні та (або) трансплантації органів і (або) тканин живої чи померлої людини, а також при іншому впливі на тіло живої чи померлої людини з цією метою, і такі, що мають місце: по-перше, між донором, реципієнтом і установою охорони здоров'я, яка здійснює забір, заготовку й трансплантацію органів і (або) тканин людини, або, подруге, між родичами чи виконавцями волевиявлення померлого та установи охорони здоров'я, яка здійснює забір, заготовку й трансплантацію органів і (або) тканин людини, або, по-третє, між реципієнтом і установою охорони здоров'я, яка здійснює забір, заготовку й трансплантацію органів і (або) тканин людини [3, с. 8-9].

Отже, зважаючи на специфіку змісту правовідносин, пов'язаних із трансплантацією, їх необхідним суб'єктом постає установа охорони здоров'я (медичний заклад), уповноважена технологічно забезпечити відповідний процес.

Вказівку на досить суттєвий показник складності феномену трансплантації містить позиція О.М. Степанової, яка відзначає, що трансплантація органів людини - це складне соціально-правове завдання, яке передбачає неодмінність врахування: інтересів реципієнтів, тобто хворих, які потребують пересадки; нестачу донорських органів («катастрофічну»); дотримання цивільних прав живих донорів та родичів померлих, у яких вилучаються органи для трансплантації; прогресивного розвитку трансплантології, що неможливо без випереджуючого правового регулювання; етичних, духовних та релігійних цінностей конкретного суспільства [4, с. 17].

Окремі російські дослідники проблем правового регулювання трансплантації, виходячи із законодавчого формулювання поняття, виділяють основні іiі ознаки, а саме: вид медичного втручання; стосується лише органів і тканин людини; є засобом спасіння життя; має на меті відновлення здоров'я; підзаконний характер діяльності; 
гуманістична спрямованість; пріоритет інтересів особи над інтересами суспільства чи науки [5, с. 7].

У цілому трансплантація переслідує соціально корисну мету спасіння життя та відновлення здоров'я пацієнта. Водночас варто пам'ятати, що заміні пошкодженого органу чи тканини передує вилучення останніх з тіла донора. В такий спосіб, до прикладу, при прижиттєвому донорстві не йдеться про відновлення його здоров'я, адже вилучення органу чи тканини від донора носить невідновний характер [6, с. 86]. Отже, в якості результатів процедури трансплантації відбувається взаємозалежність втрати та набуття. 3 одного боку, реципієнт набуває для себе благо в вигляді органу чи тканини, яких він потребував для життя і повноцінного функціонування його організму, з іншого ж донор зазнає втрати блага через передачу потрібних реципієнту органу чи тканини. Враховуючи зазначений фактор, цілком справедливо називати донорство органів і тканин альтруїстичною діяльністю, незважаючи на те, що донор може отримувати певну грошову компенсацію (можливість відшкодування йому певних витрат). Адже втрата, якої зазнає донор через пересадку його органів чи тканин реципієнту, вже незворотна.

Таким чином, короткий аналіз основних підходів до трактування трансплантації засвідчує, перш за все, складність іiї провадження, оскільки безпосередньо сама медична процедура $\epsilon$ складною за своєю сутністю. Окрім того, сам феномен трансплантації, як стає очевидним, на сьогодні спричинює низку проблемних моментів, що мають місце в суспільстві, так як передбачає необхідність врахування: релігійних, ментальних та в цілому культурних особливостей; морально-етичних та фінансових аспектів; індивідуальних та суспільних інтересів; фактору нестачі донорських матеріалів (як правило, гострої). Все це, безперечно, актуалізує необхідність звернення до досліджуваної тематики i в наступних наукових розвідках.

\section{Література:}

1. Гашина Н.Н., Зайцева О.В. Трансплантация органов и тканей человека: понятие и сущность содержания. Вестник государственного $u$ муниципального управления. 2014. № 3. С. 47-54.

2. Пішта В.І. Адміністративно-правове регулювання трансплантації в Україні: дис. д-ра філос. за спец. 081 «Право». Ужгород, 2020. 229 с.

3. Донцов Д.С. Роль гражданско-правовых норм в регулировании общественных отношений по клинической трансплантации: автореф. дисс. канд. юрид. наук; спец.: 12.00.03. Ростов-на-Дону, 2011. 25 с. 
4. Степанова Е.Н., Малярчук В.И., Степанов Н.В. О «презумпции согласия» в правовом регулировании трансплантации органов человека. Вестник РУДН. Медищина. 2002. № 3. С. 17-22.

5. Капитонова Е.А., Романовская О.В., Романовский Г.Б. Правовое регулирование трансплантологии. Монография. М.: Проспект, 2016. 144 c.

6. Алсынбаева Э.М. Правовая природа трансплантационной медицинской помощи. Правовое государство: теория и практика. 2015. № 4. С. 85-90.

DOI https://doi.org/10.30525/978-9934-26-148-0-10

\title{
СХЕМА ОЦІНЮВАЛЬНОГО СИНТЕЗУ ЯК ОСНОВА ДЛЯ ПРАВИЛЬНОГО РОЗУМІННЯ НОРМ ДЛЯ ВИРІШЕННЯ ЄВГЕНА ЕРЛІХА
}

\author{
Савчук В. Г. \\ аспірантка кафедри теорї права та прав людини \\ Чернівецького національного університету імені Юрія Федьковича \\ м. Чернівиі, Україна
}

Євген Ерліх (про нього і його творчість докладно див. [1; 2]) є автором теорії норм для вирішення, яким він присвятив однойменну главу в «Заснуванні соціології права» (1913/1989) [3, с. 111-123]. Ці ж норми він активно використовував в «Юридичній логіці» (1917/18) $[4 ; 5]$, в оригінальному і дуже цікавому предметному покажчику до якої, що міститься тільки в монографічному виданні, наводиться таке визначення-схема цих норм:

«Норми для вирішення:

- Поняття: Норми, згідно з якими суддя вирішує правовий спір ...

- використання яких для побудови правових понять ...

- могло б виводитися із загальних принципів, які запозичуються із правоположень завдяки індукції, для інших, ніж уже вміщених в правоположеннях рішень, виводитися тільки за допомогою повторного зважування інтересів» [5, с. 320].

Норми для вирішення отримали визнання в сучасній філософії $\mathrm{i}$ теорії права, а в також в юридичній методології і теорії юридичної аргументації (Фр. Мюллер, Р. Алексі, Хр. Фішер та ін.). Водночас наведене вище визначення $€$. Ерліха відображає дух часу, в який воно було написано, проте зміни, які відбулися за останні більш, ніж 